\title{
DETERMINANTS OF STUDENTS' PERFORMANCE IN FINANCIAL ACCOUNTING AND COMMERCE IN FEDERAL GOVERNMENT COLLEGES IN KANO STATES, NIGERIA.
}

\author{
MOHAMMED Abdulrazak \\ 1 Business Education Section,Faculty of Education Technology,AbubakarTafawaBalewa \\ University,Bauchi
}

ARTICLE INFO

Keywords:

\begin{abstract}
The general objective of this study was determinants of students' performance in financial and commerce accounting in Federal Government Colleges of Kano state. Four specific objectives, research questions and hull hypotheses were raised for the study. For the purpose this study, different books were reviewed both published and unpublished materials. Descriptive survey research design was used for this study. The population for the study was two hundred and seventy nine (279). This consists of twenty two (22) Financial Accounting teachers and (257) Financial Accounting subjects' students in SS1 sand SS2 from Federal Government Colleges of Kano State. Questionnaire was administered to both teachers and students for data collection. The data collected were analyzed by using mean, standard deviation and $t$-test. Null hypothesis was raised and tested with $t$-test statistic tool at 0.05 level of significance. The null hypothesis raised and tested, was accepted. Based on the findings, it was concluded that if students are not discouraged by their parents from taking financial accounting and Commerce, students will pass their examinations with good grade that will enable then go for further studies, and recommendations were made for the study.
\end{abstract}

Introduction The falling in standard of education has become an issue of concern of Nigerian's today. Parent's unhappiness becomes more pronounced flowing the annual release of senior secondary school certificate examination (SSCE) result by either West African Examination Council (WAEC) or the National Examination Council (NECO). Parent's investment does not match with the student's achievements using the annual WAEC and NECO result analysis. Stakeholders in education are concerned about why the system is turning out graduate with poor

$\square$ Corresponding Author E-Mail Address: abhabiba086@gmail.com 2538-919X / @ 2018 JARSS. All rights reserved. 
results especially at secondary school level. The falling in standard of education becomes more worrisome as it greatly affects the public secondary schools.

Commercial subjects originated from Business Education programmes offered at both secondary and tertiary level in private and public institutions for job skills, employment and self-reliance. Financial Accounting as a subject is taught at the junior secondary level which is integrated in business studies. At senior secondary school level, financial accounting offered as a full fledge subject based on the scope of the syllabus at that stage. It is offered as a course of study in colleges of education, polytechnics and universities. Other business subjects include office practice, marketing, shorthand, typewriting, commerce and economics.

Financial Accounting plays a vital role in the economy for effective development. Financial Accounting according to Okwuanaso and Nwazor (2001), is the process of collecting, recording, analysis and summarizing in monetary form, information about an organization. Longe and Kazeem (1999) defined accounting as the process of recording, classifying, selecting, measuring, interpreting and communicating financial data of an organization to enable the users make assessments and decision.

\section{Statement of the Problem}

Financial Accounting is skill development subjects which prepare the learners to be self-reliant as contained in the National Policy on Education (NPE 2004). However, in recent times, the Senior Secondary Certificate Examination (SSCE) has proved that the aim may not be attained. In federal government colleges, the concept, principles and procedures of Financial Accounting are taught in abstract which make it difficult to be understood by learner. Before now teachers that are supposed to be with these students are not regularly available and even when they are, they are not prepared for the lesson. Time allocation and period of the lesson are usually in the afternoon, most at times students complain bitterly about the time which makes it very difficult for them to comprehend the lesson, since it involves calculations. Effects of these variables would cause poor performance in the subject.

At West African Examination Council (WAEC) and National Examination Council (NECO), marking center in Kaduna for the past five (5) years, downward trend in students' performance in Financial Accounting at SSCE had dominated the discussion within the school. Interaction of the researcher with some Financial Accounting teachers and students in the school revealed continuous failure of the students in the subjects. Confirming this poor performance, Udoh (2003), remarked that in spite of the laudable objectives of Financial Accounting, students' performance at their final examination in the subjects has been negatively skewed consecutively for the past four years. According to Udoh (2003), students' credit passes in Financial Accounting within Kaduna Educational Zone stood at 42\%, 38\%, 35\% and 32\% respectively from 2007-2010.

Records have also shown a decline in the performance of students' in both WAEC and NECO in Financial Accounting in Federal Government College Kaduna and Kano States. 


\section{Research Methodology}

Descriptive survey research design was adopted in order to carry out this study. The bases for adopting this method is to enable the researcher ascertain the opinions of both staff and commercial subject's students. These opinions shall focus on the determinants of students' performance in commerce and financial accounting. Descriptive survey research according to Nworgu (2001) is concerned with the collection of data for the purpose of describing and interpreting existing conditions, prevailing practices, beliefs and attitudes and so on. It enabled the researcher to identify the present conditions, the prevailing needs as well as obtain relevant information in a systematic manner that will generate sound result.

\section{Test of Null Hypotheses}

The hypothesis formulated for this study was tested using table 4.3.1 as follows:

\subsubsection{Analysis of Null Hypothesis 1}

Parents have no significant influence on students' performance in financial accounting and commerce in Federal Government Colleges in Kano States, Nigeria

To test this hypothesis, t-test was method was used. The result obtained were presented in table 4.3.2 below

Table 4.3.1: t-test for parental influence on students' performance in financial accounting and commerce

\begin{tabular}{llllllc}
\hline Variable & Mean & S/D & Calculated & Critical & DF & Sig(2-tail) \\
\hline $\begin{array}{l}\text { Parental } \\
\text { influence }\end{array}$ & 2.58 & 0.77 & & & & \\
Students & 2.74 & 0.51 & 0.228 & 0.196 & 277 & 0.03 \\
$\begin{array}{l}\text { Performance } \\
\text { Source:-Field }\end{array}$ & & & & & \\
\hline
\end{tabular}

Source:-Field Study 2018

The result in table 4.3.1 showed that mean for parents influence 2.58, for students performance 2.74 , standard deviation were 0.77 and 0.51 respectively. The Calculated value was 0.228 , degree of freedom 277, Table value was 0.196 and level of significant 0.03 at alpha value of 0.05. The result in table 4.3.2 showed that calculated value of 0.228 was found to be significant at 0.03 at level of alpha value 0.05 . This is because the calculated value of 0.228 is greater than the critical value which is 0.196 at degree of freedom of 277 . In this study, since the calculated value is higher than the critical value, there is significant influence on parents influence on students' performance in financial accounting and commerce. The null hypothesis which states that there is no significant influence on parents influence on students' performance is therefore rejected.

\section{Discussion of Major Findings}

Based on the analysis on research question one in table 4.2.1 showed the parent's influences on students' performance in financial accounting and commerce by the aggregate mean scores of 2.26 which fall under the categories of disagree. This implies that both teacher's and students' of these colleges disagree with the parent's influence on students' performance in Federal Government 
Colleges under study. This is in line with the null hypothesis two in table 4.3 .1 which showed that there is positive difference between the parent's influence and students' performance in financial accounting and commerce in Federal Government Colleges, Kano state, Nigeria $(\mathrm{P}=0.228)$. This means that the null hypothesis is rejected and the alternative is upheld. That is, there is significance influence between the parent's and students' performance in financial accounting commerce in Federal Government Colleges, Kano State, Nigeria. This means that the respondents disagree with the parent's influence on students' performance in the Federal Government Colleges under study. The parent's negative influence may be as a result of lack of awareness about the importance of commercial subjects among others. In order to buttress this, Aremu (2000) pointed out that students' home environment, their cognitive abilities, self concept and study habit affects their academic success. Conclusion

Based on the major findings from the result of the analysis presented, the following conclusions were drawn, if students were not discouraged by their parents from taking financial accounting and commerce, students will pass their examinations with good grade that will enable then go for further studies.

\section{Recommendations}

Upon the conduct of research which resulted in accepting hypothesis formulated, the researcher is suitable to make the following recommendations based on the findings.

1. Policy and procedure for students' placement into financial accounting class should be strictly on merit.

2. Parents and stakeholder should encourage students' to take financial accounting as the objective of the course is to make individual self-reliance upon successful completion of the course.

3. Group of friends they associate with, should be thoroughly checked by the college so as to enhance their performance in the subject during West African Examination Council (WAEC) and National Examination Council (NECO). If this is done, students will pass financial accounting with good grade that will enable them go for further studies. 


\section{References}

Longe, O.A. and Kazeem, R.A. (1999).Essential Financial Accounting for Senior Secondary Schools. Lagos: Tonad Publishers Ltd.

Nworgu, B.G. (2001). Educational Research Basic Issue and Methodology, Wisdom Publishers Ltd. Owerri, pp.25-30.

Odedokun, M.O. Udokogu, P.C. and Oguji, C.O.N. (2002).Commerce for Senior Secondary Schools. Jott Ltd, Lagos pp.4-10.

Okwuanaso, S.I. and Nwazor, J.C. (2001).Instructional Strategies in Business Education. Awka: Ikenga Publishers.

Udoh, A.A. (2003). Business Education Teacher's Perceptive Assessment of Secondary School Students Academic University. Journal of Vocational Studies, Vol. No. 1 pp. 8 - 14.

Zwangina, J.S. (2009). Ongoing reforms in the Federal Unity Colleges, Unity watch. 4:71-74. 